\title{
Sesame oil enhances endogenous antioxidants in ischemic myocardium of rat
}

\author{
T. S. Mohamed Saleem, ${ }^{*}$, C. Madhusudhana Chetty, ${ }^{2}$ S. \\ Kavimani $^{3}$
}

${ }^{1}$ Jawaharlal Nehru Technological University, Kakinda \& Department of Pharmacology, Annamacharya College of Pharmacy, India,

${ }^{2}$ Department of Biotechnology, Annamacharya College of Pharmacy, India

${ }^{3}$ Department of Pharmacology, Mother Theresa Post Graduate and Research

Institute of Health Sciences, India.

\begin{abstract}
The present study was designed to evaluate the potency of antioxidant activity of sesame oil in-vitro model of myocardial ischemic reperfusion injury of rat. Sesame oil was administered orally to Wistar albino rats (180-200 g) in two different doses ( $\mathrm{n}=6)$, by gastric gavage at a dose of $5 \mathrm{~mL} / \mathrm{kg}$ b.w. (S1) and $10 \mathrm{~mL} / \mathrm{kg} \mathrm{b.w} \mathrm{(S2)}$ daily for thirty days. Control and sesame oil treated rat hearts were subjected to invitro global ischemic reperfusion injury ( $5 \mathrm{~min}$ perfusion, 9 min noflow and $12 \mathrm{~min}$ reperfusion). A significant rise in TBARS and decrease of GSH, catalase, LDH, CK and AST occurred in the hearts subjected to in-vitro myocardial ischemic reperfusion injury indicate the myocardial damage through oxidative stress. In sesame oil treated rats there was a significant decrease in TBARS and significant increase in endogenous antioxidants and myocardial marker enzymes in all the groups. In $10 \mathrm{~mL} / \mathrm{kg}$ treatment group, a significant rise in the levels of GSH, SOD and catalase were observed with marker enzymes, and it shows better recovery profile than the other groups subjected to in-vitro ischemic reperfusion injury. In histological studies, control rats which subjected to IR injury show extensive myocardial damage and all the treatment groups, shows preserved myocardium. The effect of sesame oil was compared with reference compound captopril. The present study demonstrates that the sesame oil treated by the dose $10 \mathrm{~mL} / \mathrm{kg}$ augments endogenous antioxidant compounds of the rat heart and also prevents the myocardium from in-vitro model of myocardial ischemic reperfusion injury.
\end{abstract}

Revista Brasileira de Farmacognosia Brazilian Journal of Pharmacognosy 22(3): 669-675, May/Jun. 2012

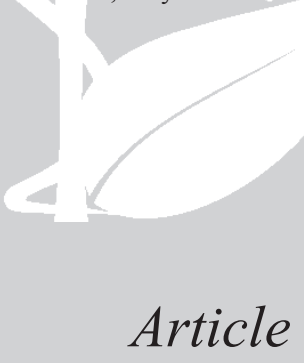

Received 10 Oct 2011

Accepted 8 Jan 2012

Available online 3 Feb 2012

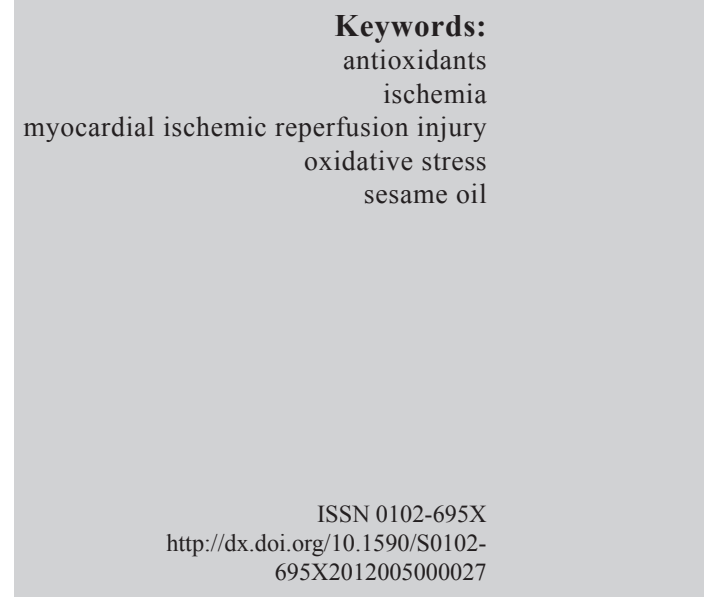

\section{Introduction}

Cardiovascular disease (CVD) has become known life threatening problem for the world. The risk factors and higher mortality from CVD has been proved without doubt from well developed countries of Western Europe, North America, and East Asia, as well as for the vast majority of developing countries and even the large urban centers of sub-Saharan Africa (Ramahi, 2010). A recent report from World Health Organization (WHO) stated that mortality from CVD in countries of Sothern Asia, including India, Pakistan, and Bangladesh, is not as high as that of Central Asian countries, but is significantly higher than that of East Asian countries (WHO, 2010). Moreover WHO reported that high mortality due to ischemic heart disease (IHD) in India is associated with less than 70 years of age and the death rate due to myocardial infarction (MI) is occurred in the age between 40 to 50 (Panwar et al., 2011; Kumar et al.,
2011). Large variation, however, likely exists within these countries between urban and nonurban populations. The most majority of risk factors for this overall mortality are industrial exposure according to their profession, changing dietary habits, lifestyle and increasing obesity. Moreover, tobacco smoking is highly prevalent and risk factors for atherosclerosis tend to occur earlier in life, accounting for earlier presentation of CVD events (Panwar et al., 2011; Ramahi, 2010).

Reperfusion of the ischemic myocardium plays a major role for the management of patients with acute obstruction of coronary arteries. During the reperfusion the myocardial tissue undergo morphological changes suggest that reperfusion injury is a true pathological phenomena. Oxidative stress is evidence for the development of IHD and its consequences. During reperfusion molecular oxygen undergo reduction to generate oxygen free radicals (OFR) like superoxide anion and hydroxyl radical which interact with cell 
membrane lipid and essential proteins leads to cause myocardial damage which is well established in animal and human experimental condition (Bolli, 1998; Banerjee et al., 2002). Oxidant stress, due to overwhelming generation of OFR, with concomitant depletion of certain key endogenous components, e.g., superoxide dismutase (SOD), reduced glutathione (GSH), and catalase, play an important role in the ischemic reperfusion injury (IRI) of heart (Gallagher et al., 1986; Ferrari et al., 1991; Downey \& Yellon, 1992; Halliwell, 2000).

Natural antioxidants play a major role to reduce the oxidative stress by scavenging the excess free radicals (Ahmad et al., 2011). Administration of antioxidants (which present in plant extracts, food supplements and even drugs) during reperfusion injury has been shown to reduce the severity of IRI through augmentation of endogenous antioxidants have been identified as a promising therapeutic approach to combat oxidative stress associated with IHD (Visweswaran et al., 1997; Banerjee et al., 2002).

From ancient time globally the peoples were using the sesame oil as dietary source. Sesame oil is known dietary source having putative antioxidant property (Saleem \& Gauthaman, 2009). Sesame oil, derived from the seeds of plant species of Sesamum indicum L. belongs to family Pedaliaceae, consists of various fatty acids and nonfat antioxidants, including tocopherol, sesamin, sesamolin, and sesamol (Fukuda, 1990). The potential antioxidant, gastro protection and anti-inflammatory effect were reported earlier. It helps regulate the body's immune and auto immune system balance. It inhibits a set of regulating compounds, which cause inflammation, clotting and other immune imbalances that contribute to disorders such as heart disease and autoimmune joint disorders. Consumption of sesame oil as dietary source may help to enhance antioxidant defense system in humans (Saleem \& Gauthaman, 2009). Ahmad et al., (2011) reported the anti-oxidative property of sesame oil in 6-hydroxydopamine induced neurotoxicity. The present investigation is undertaken to find out the potency of antioxidant activity of chronic administration of sesame oil and to estimate the cardio protective action rendered by sesame oil.

\section{Material and Methods}

\section{Drugs and chemical}

Sesame oil was obtained from Idhayam sesame oil as gift sample. All chemicals were of analytical grade purchased from sigma chemicals, UsA.

\section{Collection and test for oil}

The sesame oil identification test was carried out following the procedure given in the British Pharmacopoeia, 1993: Shake $10 \mathrm{~mL}$ with a mixture of $4.5 \mathrm{~mL}$ of acetic anhydride and $0.5 \mathrm{~mL}$ of a $0.35 \%$ $\mathrm{v} / \mathrm{v}$ solution of furfuraldehyde in acetic anhydride in a cylinder fitted with a ground glass stopper, filter through a filter paper impregnated with acetic anhydride and add to the filtrate $0.2 \mathrm{~mL}$ of sulphuric acid. A bluish green colour is produced. Baudouin's test given by Wallis was also carried out: sesame oil $(2 \mathrm{~mL})$ is mixed with $1 \mathrm{~mL}$ of $\mathrm{HCl}$ containing $1 \%$ of sucrose and shaken for $1 / 2$ min. Pink aqueous layer indicates the presence of sesame oil. Voucher specimen sample (ANCP-MP-108) was deposited in the Department of Pharmacognosy, Annamacharya College of Pharmacy, Rajampet.

\section{Phytochemical analysis of sesame oil}

The sesame oil was subjected to preliminary phytochemical screening, to identify the chemical constituents. The methods of analysis employed were those described in standard procedures (Trease \& Evans, 1989; Harbone \& Baxter, 1993).

\section{Experimental animals}

Male Wistar albino rats of body weight 180-200 $\mathrm{g}$ were obtained from the Institute Animal House. The animals were fed on standard pellet diet (Hindustan Lever, Mumbai, India) and water ad libitum. The rats used in the this study were maintained in accordance with guidelines of the Committee for the Purpose of Supervision and Control of Experiments on Animals (CPCSEA), India and the study was approved by the Institute Animal Ethical Committee (1220/a/08/CPCSEA/ANCP).

\section{Experimental methods}

Rats were randomly divided into four groups $(n=6)$ and the sesame oil was fed by oral gavage everyday for thirty days in two doses $5,10 \mathrm{~mL} / \mathrm{kg}^{-1}$ body weight. Control rats were fed vehicle (Saline $10 \mathrm{~mL} / \mathrm{kg}$ ) daily for thirty days. After $48 \mathrm{~h}$ of the last dose rats were heparinised (375 units/200 g i.p.) (Neely et al., 1972), and half an hour later rats were anaesthetized with pentobarbitone sodium $\left(60 \mathrm{mg} / \mathrm{kg}^{-1}\right)$ and subjected to the following protocol.

\section{Production of in-vitro ischemic-reperfusion injury}

Hearts were rapidly excised and washed in icecold saline and then perfused by the non-recirculating Langendorff's technique (Inco, Ambala), in constant pressure mode using a modified Kreb's Henseleits solution ( $\mathrm{pH} 7.4$ ) containing (in $\mathrm{mM}$ ): glucose $11.1 ; \mathrm{NaCl}$ 118.5; $\mathrm{NaHCO}_{3} 25 ; \mathrm{KCl} 2.8 ; \mathrm{KH}_{2} \mathrm{PO}_{4} 1.2 ; \mathrm{CaCl}_{2} 1.2$; 
$\mathrm{MgSO}_{4}$ 0.6, with a $\mathrm{pH}$ of 7.4. retrograde aortic perfusion was initiated at a perfusion pressure of $60 \mathrm{~mm} \mathrm{Hg}$ and the heart temperature was maintained at $37^{\circ} \mathrm{C}$ by water jacketing the reservoir and the isolated hearts. Following 5 min equilibration period, hearts were subjected to $9 \mathrm{~min}$ of no-flow (ischemia) and 12 min of re-flow (reperfusion) to produce IR injury (Borchgrevink et al., 1989; Maulik et al., 1999; Gauthaman et al., 2001). 26 min flow

Group C: vehicle- treated rat hearts subjected to

Group C-IR: vehicle- treated rat hearts subjected to $5 \mathrm{~min}$ flow $+9 \mathrm{~min}$. no-flow $+12 \mathrm{~min}$. reflow.

Group S1: $5 \mathrm{~mL} / \mathrm{kg} /$ day for thirty days of sesame oil treated rat hearts subjected to $5 \mathrm{~min}$ flow $+9 \mathrm{~min}$. noflow +12 min reflow.

Group S2: $10 \mathrm{~mL} / \mathrm{kg} /$ day for thrity days of sesame oil treated rat hearts subjected to 5 min flow +9 min no-flow +12 min reflow.

Group CAP: $10 \mathrm{mg} / \mathrm{kg} /$ day for thirty days of captopril treated rat hearts subjected to $5 \mathrm{~min}$ flow $+9 \mathrm{~min}$ no-flow +12 min reflow.

At the end of each experiment, cardiac tissue samples were stored in nitrogen container at $-80{ }^{\circ} \mathrm{C}$ for biochemical estimations, and in $10 \%$ buffered formalin for histological studies.

\section{Biochemical parameters}

The following biochemical parameters were studied in the heart homogenate.

Myocardial thiobarbituric acid reactive substances (TBARS)

TBARS activity in the myocardium was determined by a modified version of the method described by Okhawa et al. (1979). Hearts were homogenized in $10 \%$ trichloro acetic acid in $4{ }^{\circ} \mathrm{C}$. A $0.2 \mathrm{~mL}$ homogenate was pipetted in to a test tube, followed by the addition of $0.2 \mathrm{~mL}$ of $8.1 \%$ sodium dodecyl sulphate (SDS), $1.5 \mathrm{~mL}$ of $20 \%$ acetic acid (pH-3.5) and $1.5 \mathrm{~mL}$ of $0.8 \%$ TBA. Tubes were boiled for $60 \mathrm{~min}$ at $95^{\circ} \mathrm{C}$ and then cooled in ice. Double distilled water $(1.0 \mathrm{~mL})$ and $\mathrm{n}$-butanol:pyridine $(15: 1 \mathrm{v} / \mathrm{v})$ mixture $(5.0 \mathrm{~mL})$ were added to the test tubes and centrifuge at $4000 \mathrm{x}$ g for $10 \mathrm{~min}$. The absorbance of developed colour in organic layer was measured at 532 $\mathrm{nm}$. Data are expressed as nmole of TBARS/g wet.wt.

\section{Myocardial reduced glutathione (GSH)}

GSH was estimated by the method of Ellman et al. (1959). The reaction mixture contained $0.1 \mathrm{~mL}$ of supernatant, $2.0 \mathrm{~mL}$ of $0.3 \mathrm{M}$ phosphate buffer $(\mathrm{pH}-8.4)$, $0.4 \mathrm{~mL}$ of double distilled water and $0.5 \mathrm{~mL}$ of DTNB $(5,5$ dithiobis-2-nitrobenzoic acid). The reaction mixture was incubated for $10 \mathrm{~min}$ and the absorbance was measured at $412 \mathrm{~nm}$. Data are expressed as mole/g wet.wt.

Superoxide dismutase (SOD)

SOD levels in the hearts were determined by the method of McCord \& Firdovich method (1969) and modified by Kakkar et al., 1984. A sample $(0.6 \mathrm{~mL})$ was added to sodium pyrophosphate buffer (pH-8.3) followed by addition of $0.1 \mathrm{~mL}$ of $186 \mathrm{M}$ phenazine methosulphate, $0.3 \mathrm{~mL}$ of $300 \mathrm{mM}$ nitroblue tetrazolium and $0.2 \mathrm{~mL}$ of $780 \mathrm{M}$ NADH. Reaction mixture was incubated for $90 \mathrm{~s}$ at $30{ }^{\circ} \mathrm{C}$ and stopped the reaction by adding $1 \mathrm{~mL}$ of acetic acid. n-Butanol (4 mL) was then added and centrifuged at $3000 \mathrm{x}$ g for $10 \mathrm{~min}$. The absorbance of organic layer was measured at $560 \mathrm{~nm}$. Data are expressed as units per mg protein.

\section{Estimation of catalase}

Catalase was estimated by the method described by Aebi \& Bergmeyer (1974). Sample was added to a 3 $\mathrm{mL}$ cuvette that contained $1.95 \mathrm{~mL}$ of $50 \mathrm{mM}$ phosphate buffer (pH-7.0). Then $1 \mathrm{~mL}$ of $30 \mathrm{mM}$ hydrogen peroxide was added and changes in absorbance were followed for $30 \mathrm{~s}$ at $240 \mathrm{~nm}$ at an interval of $15 \mathrm{~s}$. Data are expressed as units per mg protein.

\section{Estimation of protein}

Protein estimation for the tissue sample of SOD and catalase were done by the method of Bradford (1976). Sample was added up to $20 \mu \mathrm{L}$ with double distilled water, $50 \mu \mathrm{L}$ in $\mathrm{NaOH}$ and $1 \mathrm{~mL}$ of Bradford reagent and vortexes and kept for $10 \mathrm{~min}$ and the absorbance was measured at $595 \mathrm{~nm}$.

LDH levels in the myocardium were determined by the method described by King (1959). Creatine kinase (CK) \& Aspartate transaminase (AST) levels in the myocardium were determined by the method by Saxena et al. (1988).

\section{Histological examination}

The rat hearts were removed, washed immediately with saline and then fixed in $10 \%$ buffered formalin. The hearts were embedded in paraffin sections cut at $5 \mu$ stained with haematoxylin and eosin. These sections were then examined under the light microscope for histological changes.

\section{Statistical analysis}

All values are expressed as mean \pm SEM. Data for various biochemical parameters were analyzed using 
analysis of variance (ANOVA) (GraphPad Version 3.06, La Jolla, CA, USA). Significance is set at $p<0.05$.

\section{Results}

\section{Preliminary phytochemical screening}

The sesame oil was subjected to preliminary phytochemical analysis, which revealed the presence of proteins, phytosterols, lignans, saponins, fixed oils, fats, gums and mucilages.

\section{Biochemical parameters}

The results of biochemical parameters were present in Table 1, 2 .

Table 1. Effect of chronic administration of Sesame oil on TBARS, GSH, SOD and catalase in rat heart homogenate.

\begin{tabular}{|c|c|c|c|c|}
\hline \multirow[b]{2}{*}{ Groups } & \multicolumn{4}{|c|}{ Parameters } \\
\hline & $\begin{array}{c}\text { TBARS } \\
\text { nmol/g wet } \\
\text { wt }\end{array}$ & $\begin{array}{c}\text { GSH } \\
\mu \mathrm{g} / \mathrm{g} \text { wet wt }\end{array}$ & $\begin{array}{c}\text { SOD } \\
\text { I.U/mg } \\
\text { protein }\end{array}$ & $\begin{array}{l}\text { Catalase } \\
\text { I.U/mg } \\
\text { protein }\end{array}$ \\
\hline Group C & $47.64 \pm 0.38$ & $390.6 \pm 1.04$ & $3.2 \pm 0.9$ & $69.7 \pm 1.08$ \\
\hline Group C-IR & $170.3 \pm 4.9^{\mathrm{a}}$ & $164.9 \pm 20.8^{\mathrm{a}}$ & $1.6 \pm 0.4^{\mathrm{ns}}$ & $25.8 \pm 5.2^{\mathrm{a}}$ \\
\hline $\begin{array}{l}\text { Group S1 } \\
\text { (Sesame oil } \\
5 \mathrm{~mL} / \mathrm{kg} \text { ) }\end{array}$ & $45.9 \pm 3.9^{b}$ & $333.9 \pm 13.4^{b}$ & $1.8 \pm 0.3^{\mathrm{ns}}$ & $49.6 \pm 3.5^{\mathrm{ns}}$ \\
\hline $\begin{array}{l}\text { Group S1 } \\
\text { (Sesame oil } \\
10 \mathrm{~mL} / \mathrm{kg} \text { ) }\end{array}$ & $57.3 \pm 6.0^{\mathrm{b}}$ & $328.6 \pm 16.6^{b}$ & $5.2 \pm 0.3^{\mathrm{b}}$ & $129.8 \pm 12.4^{b}$ \\
\hline $\begin{array}{l}\text { Group CAP } \\
\text { (Captopril } \\
10 \mathrm{mg} / \mathrm{kg} \text { ) }\end{array}$ & $56.0 \pm 4.3^{\mathrm{b}}$ & $340.3 \pm 32.3^{b}$ & $1.6 \pm 0.5^{\mathrm{ns}}$ & $63.3 \pm 5.6^{\mathrm{b}}$ \\
\hline
\end{tabular}

Table 2. Effect of chronic administration of Sesame oil on LDH, CK and AST in rat heart homogenate.

\begin{tabular}{lccc}
\hline \multirow{2}{*}{ Groups } & \multicolumn{3}{c}{ Parameters } \\
\cline { 2 - 4 } & LDH U/1 & CK U/1 & AST U/1 \\
\hline Group C & $159 \pm 0.06$ & $7.96 \pm 0.02$ & $190 \pm 0.01$ \\
Group C-IR & $72 \pm 0.03^{\mathrm{a}}$ & $4.35 \pm 0.02^{\mathrm{a}}$ & $82.34 \pm 0.23^{\mathrm{a}}$ \\
$\begin{array}{l}\text { Group S1 } \\
\text { (Sesame oil 5 mL/kg) }\end{array}$ & $132 \pm 0.4^{\mathrm{b}}$ & $8.23 \pm 0.21^{\mathrm{b}}$ & $112 \pm 0.32^{\mathrm{b}}$ \\
$\begin{array}{l}\text { Group S1 } \\
\text { (Sesame oil 10 mL/kg) }\end{array}$ & $139 \pm 0.23^{\mathrm{b}}$ & $7.12 \pm 0.45^{\mathrm{b}}$ & $161 \pm 0.92^{\mathrm{b}}$ \\
$\begin{array}{l}\text { Group CAP } \\
\text { (Captopril 10 mg/kg) }\end{array}$ & $121 \pm 0.76^{\mathrm{b}}$ & $6.98 \pm 0.5^{\mathrm{b}}$ & $156 \pm 0.2^{\mathrm{b}}$ \\
\hline All valua & & & \\
\hline
\end{tabular}

All values are expressed as Mean \pm SEM [n=6] ${ }^{a} p<0.001$ vs Control [C] ${ }^{\mathrm{b}} p<0.001$ vs C-IR [One way ANOVA].

\section{Myocardial TBARS}

There was significant $(p<0.001)$ increase in
TBARS level in C-IR group when compared to the control C. There was significant $(p<0.001)$ decrease in the level of TBARS in groups S1, S2 and CAP in comparision to C-IR group.

\section{Myocardial GSH}

There was significant $(p<0.001)$ decrease in GSH level in C-IR group when compared to the control C. There was significant $(p<0.001)$ increase in the level of GSH in groups S1, S2 and CAP in comparison to C-IR group.

\section{Myocardial SOD}

There was no significant change in SOD level in C-IR group when compared to the control C. There was no significant change in the level of SOD in group S1 and significant $(p<0.001)$ increase in the level of SOD in groups $\mathrm{S} 2$ and CAP in comparison to $\mathrm{C}$-IR group.

\section{Myocardial catalase}

There was significant $(p<0.001)$ decrease in catalase level in C-IR group when compared to the control C. There was no significant change in the level of catalase in group S1 and significant $(p<0.001)$ increase in the level of SOD in groups S2 and CAP in comparison to C-IR group.

\section{Myocardial LDH, CK and AST}

There was significant $(p<0.001)$ decrease in myocardial LDH, CK and AST level in C-IR group when compared to the control $\mathrm{C}$. There was significant $(p<0.001)$ increase in the level of myocardial LDH, CK and AST in groups S1, S2 and CAP in comparison to C-IR group.

\section{Histopathological study}

Group C (Figure 1A): Light microscopy of the tissue sections of group $\mathrm{C}$ showed normal myofibrillar structure with striations, branched appearance and continuity with adjacent myofibrils.

Group C-IR (Figure 1B): Light microscopy of the tissue sections of group C-IR showed edema, focal haemorrhage and leukocyte infiltration. The muscle fibres showed vascular changes with fragmentation suggestive of necrosis.

Group S1 (Figure 1C): Light microscopy of the tissue sections of group S1 subjected to IR injury showed minimal changes of myofibrillar structure with striations, and low level inflammation.

Group S2 (Figure 1D): Light microscopy of the 
tissue sections of group S2 subjected to IR injury showed normal myofibrillar structure with striations, branched appearance and continuity with adjacent myofibrils.

Group CAP (Figure 1E): Light microscopy of the tissue sections of group CAP subjected to IR injury showed normal architecture of myofibrillar structure with mild edema. The morphology of cardiac muscle fibres was relatively well preserved.

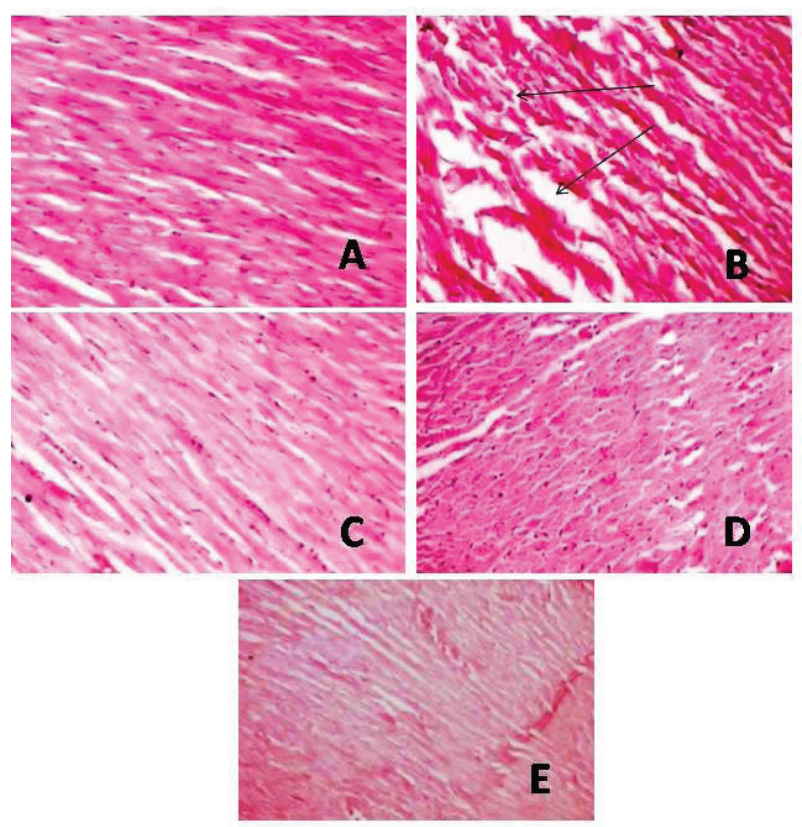

Figure 1. A. Light microscopy section of group C rat myocardium showing well maintained myofibrillar structure. B. Light microscopy section of group C-IR rat myocardium showing extensive degeneration of myofibrils with leukocytic accumulation, edema and vacuolization. C. Light microscopy section of group S1 (Sesame oil $5 \mathrm{~mL} / \mathrm{kg}$ ) showing preserved myocardium. D. Light microscopy section of group S2 (Sesame oil $10 \mathrm{~mL} / \mathrm{kg}$ ) showing preserved myocardium. E. Light microscopy section of group CAP (Captopril $10 \mathrm{mg} / \mathrm{kg}$ ) showing preserved myocardium.

\section{Discussion}

In-vitro myocardial ischemic reperfusion injury in rat heart model was carried out to evaluate the antioxidant and cardioprotective effect of sesame oil. In the present study ischemic reperfusion injury associated with oxidative stress, as evidenced by increased myocardial TBARS level as oxidative stress marker and depletion of myocardial endogenous antioxidant system in C-IR group. Same findings have been observed earlier by other researchers in the same model (Krishenbaum \& Singal, 1993; Banerjee et al., 2002).

In the present study we observed that the oral chronic administration of sesame oil at two different doses significantly decreases the myocardial TBARS and concomitant increase in the levels of endogenous antioxidants (GSH, SOD and catalase). Elevated levels of myocardial TBARS is an indicative for increase in the oxidative stress during ischemia which might be stimulated the self protective mechanism via increasing in the level of myocardial endogenous antioxidant systems (Singal et al., 1993; Maulik et al., 1997).

Enhancement of basal endogenous antioxidant by any therapeutic alternative is presently the focus of great scientific interest (Maulik et al., 1997; Pathania et al., 1998), as it is anticipated to produce better protection against oxidative stress than any exogenously administered antioxidants. In the present study, there was a large increase in myocardial GSH, SOD and catalase activities in group $\mathrm{S} 2\left(10 \mathrm{~mL} / \mathrm{kg}^{-1}\right)$, shows the better activity augmented by sesame oil. It is particularly important that both SOD and catalase were increased, since it has been shown that an increase in cellular SOD without a concomitant rise in catalase is more harmful by favoring the formation of $\mathrm{H}_{2} \mathrm{O}_{2}$ (Yim et al., 1990; Jones et al., 1999). In this respect, the sesame oil may be a particularly useful agent, as it could enhance myocardial endogenous antioxidants, without producing any cytotoxic effects.

Another significant observation, made in the present study was the protection against oxidative stress, associated with ischemic reperfusion injury in the hearts of the rats chronically treated with the sesame oil was generation of TBARS and depletion of endogenous antioxidants following ischemic reperfusion injury were markedly inhibited in these hearts. Histopathological evidence of myocardial injury following IR injuries in sesame oil and captopril treated rat was also absent. Much research evidence suggests that the protective role of sesame oil against oxidative stress through its antioxidant mechanism (Kaur \& Saini, 2000; Nakano et al., 2002; Hsu \& Liu, 2004). It has been identified that presence of antioxidative principles like sesamin, sesamol and sesaminol might be a responsible components for its protective action (Suja et al., 2004). Therefore, the protection against myocardial IR injury in the treated rats is attributable to enhanced endogenous antioxidant activity.

To assess the extend of damage during ischemic reperfusion injury of myocardium we need to analyze the specific marker enzymes. The enzymes viz, transaminases, creatine kinase and lactate dehydrogenase serve as sensitive indices to assess the severity of myocardial injury (Sheela \& Devi, 2000). In C-IR control rats, reduction in myocardial markers LDH, CK and AST in heart homogenate confirms the onset of myocardial injury (Ithayarasi \& Devi, 1997). In the present study chronic oral administration of sesame oil and captopril caused significant change in cardiac markers LDH, CK and AST in the 5 and $10 \mathrm{~mL} / \mathrm{kg}^{-1}$ treated group. Which 
indicate sesame oil also shows protective action against the myocardial tissue damage during IR injury.

Further studies are required to investigate the precise mechanisms for changes in antioxidant enzyme expression because of oxidant stress and administration of drugs. Of particular interest will be the question of whether these drugs operate by affecting the same or different regulatory mechanisms for the expression of an antioxidant enzyme gene.

\section{Conclusion}

Thus it is concluded that the chronic oral administration of the sesame oil in rat augments myocardial endogenous antioxidants, without causing any cellular injury. This offered protection against oxidative stress associated with myocardial ischemic reperfusion injury is dose dependent.

\section{Acknowledgement}

The first author thanks to Management, Annamacharya College of Pharmacy to provide the facilities to carryout the research work

\section{References}

Aebi H, Bergmeyer HU 1974. Methods of enzymatic analysis. $2^{\text {nd }}$ ed. Chemic Academic Press Inc, Verlag, vol 2, p. 673-685.

Ahmad S, Khan MB, Hoda MN, Bhatia K, Haque R, Fazili IS, Jamal A, Khan JS, Katare DP 2011. Neuroprotective Effect of Sesame Seed Oil in 6-Hydroxydopamine Induced Neurotoxicity in Mice Model: Cellular, Biochemical and Neurochemical Evidence. Neurochem Res DOI: 10.1007/s11064-011-0638-4.

Banerjee SK, Dinda AK, Manchanda SC, Maulik SK 2002. Chronic garlic administration protects rat heart against oxidative stress induced by ischemic reperfusion injury. BMC Pharmacol 2: 16.

Bolli R 1998. Basic and clinical aspect of myocardial stunning. Prog Cardiovacs Dis 40: 477-516.

Borchgrevink PC, Schie R, Bergan AS, Bakoy OE, Jynge P 1989. Magnesium and reperfusion of ischemic rat heart as accessed by 31P NMR. Am J Physio 256: 1119511204.

Bradford MM 1976. A rabid and sensitive method for the quantization of microgram quantities of protein utilizing the principle of protein-dye binding. Anal Biochem 772: 248-254.

Downey JM, Yellon DM 1992. Do free radicals contribute to myocardial cell death during ischemia-reperfusion? Myocardial protection. The pathophysiology of reperfusion and reperfusion injury. Yellon DM, Jennings RB (eds). Raven Press, New York: p. 35-57.
Ellman GL 1959. Tissue sulphydryl groups. Arch Biochem Biophy 82: 70-77.

Ferrari R, Ceconi C, Curello S, Cargnoni A, Pasini E, Visioli O 1991. The occurrence of oxidative stress during reperfusion in experimental animals and men. Cardiovasc Drug Ther 5: 277-288.

Fukuda Y 1990. Food chemical studies on the antioxidants in sesame seed. Nippon Shokuhin Kogyo Gakkaishi 37: 484-492.

Gallagher KP, Buda AJ, Pace D, Gerren RA, Shafler M 1986. Failure of superoxide dismutase and catalase to alter size of infarction in conscious dogs after 3 hours of occlusion followed by reperfusion. Circulation 73: 1065-1076

Gauthaman K, Maulik M, Kumari R, Manchanda SC, Dinda AK, Maulik SK 2001. Effect of chronic treatment with bark of Terminalia arjuna: A study on the isolated ischemic-reperfused rat heart. $J$ Ethanopharmacol 75 : 197-201.

Halliwell B 2000. The antioxidant paradox. Lancet 355: 11791180.

Harbone JB, Baxter HH 1993. Phytochemical Dictionary: $A$ hand Book of Bioactive Compound from plants. Washington: Taylor and Francis; p. 237.

Hsu DZ, Liu MY 2004. Sesame oil protects against lipopolysaccharide-stimulated oxidative stress in rats. Crit Care Med 32: 227-231.

Ithayarasi PA, Devi CS 1997. Effect of $\alpha$-tocopherol on isoproterenol induced changes in lipid and lipoprotein profile in rats. Ind J Pharmacol 29: 399-404.

Jones SA, McArdle F, Jack CI, Jackson MJ 1999. Effect of antioxidant supplementation on the adaptive response of human skin fibroblasts to UV-induced oxidative stress. Redox Rep 46: 291-299.

Kakkar P, Das B, Viswanathan PN 1984. A modified spectrophotometric assay of superoxide dismutase. Ind J Biochem Biophy 21: 130-132

Kaur IP, Saini A 2000. Sesamol exhibits antimutagenic activity against oxygen species mediated mutagenicity. Mutat Res 470: 71-76.

King J 1959. A routine method for the estimation of lactic dehydrogenase activity. J Med Lab Tech 16: 265-272.

Krishenbaum LA, Singal PK 1993. Increase in endogenous antioxidant enzyme protects heart against reperfusion injury. Am J Physiol 265: H484-H493.

Kumar A, Khan SA, Parvez A, Zaheer MS, Rabbani MU, Zafar L 2011. The prevalence of hyperhomocysteinemia and its correlation with conventional risk factors in young patients with myocardial infarction in a tertiary care centre of India. Biomed Res 22: 225-229

Maulik G, Mukherjee S, Das DK 1997. Evaluation of antioxidant effectiveness of a new selected vegetable. Environ Nutr Interac 1: 287- 297.

Maulik M, Maulik SK, Kumari R 1999. Importance of dosage and timing of magnesium administration: A study on the 
isolated ischemic-reperfused heart. Mag Res 12: 37-42. Nakano D, Itoh C, Takaoka M, Kiso Y, Tanaka T, Matsumura Y 2002. Antihypertensive effect of sesamin. IV. Inhibitionof vascular superoxide production by sesamin. Biol Pharmacol Bull 25: 1247-1249.

Neely JR, Denton RM, England PJ, Randle PJ 1972. The effects of increased heart work on the tricarboxylate cycle and its interactions with glycolysis in the perfused rat heart. Biochem J 1: 147-159.

Okhawa H, Oohishi N, Yagi K 1979. Assay for lipid peroxides in animal tissues by thiobarbituric acid reaction. Ann Bichem 95: 351-358.

Panwar RB, Gupta R, Gupta BK, Raja S, Vaishnav J, Khatri M, Agarwal A 2011. Atherothrombotic risk factors $\&$ premature coronary heart disease in India: A casecontrol study. Indian J Med Res 134: 26-32

Pathania V, Syal N, Hundal MH, Khanduja KL 1998. Geriforte stimulates antioxidant defense system. Ind J Exp Bio 36: 414-417.

Ramahi TM 2010. Cardiovascular disease in the Asia Middle East region: global trends and local implications. Asia Pac J Public Health 22: 83S-89S.

Saleem TSM, Gauthaman K 2009. Neutraceutical value of sesame oil. Phcog Rev 36: 264-269.

Saxena KK, Gupta B, Srivastava VK, Saxena RS, Singh RC, Prasad DN 1988. Creatine kinase and aspartate transaminase in experimental model to predict the size of cardiac infarct. Indian J Exp Biol 26: 235-236.

Sheela SC, Devi CS 2000. Protective effect of Abana, a polyherbal formulation, on isoproterenol induced myocardial infarction in rats. Ind J Pharmacol 32: 198201.

Singal PK, Dhalla AK, Hill M, Thomas TP 1993. Endogenous antioxidant changes in the myocardium in response to acute and chronic stress conditions. Mol Cell Biochem 129: 179-186.

Suja KP, Jayalekshmy A, Arumughan C 2004. Free radical scavenging behavior of antioxidant compounds of Sesame (Sesamum indicum L.) in DPPH system. J Agric Food Chem 52: 912-915.

Trease GE, Evans MC 1989. Text book of Pharmacognosy. London: Bailiere Tindall; p. 200-201, 340-348, 419423, 626-630, 765-775.

Visweswaran P, Massin EK, Dubose TD 1997. Mannitol induced acute renal failure. J Am Soc Nephrol 8: 1028-1033

WHO 2010. World Health Statistics 2009. http://www.who. int/whosis/whostat/2009/ en/index.html. accessed Feb 2010 .

Yim MB, Chock PB, Stadtman ER 1990. Copper, Zinc super oxide Dismutase catalyzes hydroxyl radical production from hydrogen peroxide. Natl Acad Sci USA 8713: 5006-5010.

\section{*Correspondence}

T.S. Mohamed Saleem

Department of Pharmacology, Annamacharya College of Pharamacy

New Boyanapalli, Rajampet-516126, Andhrapradesh, India saleemcology@ancpap.in

Tel.: +91 9701978543; +919542326252 